\title{
Oral Hygiene
}

National Cancer Institute

\section{Source}

National Cancer Institute. Oral Hygiene. NCI Thesaurus. Code C60725.

The practice of keeping the mouth, teeth, and gums clean and healthy to prevent disease, as by regular brushing and flossing and visits to a dentist. 